\title{
Internal Marketing and Marketing Effectiveness of Hotel Industry in Rivers State
}

\author{
N. Gladson Nwokah*, Joyce Tamunosaki Briggs \\ Department of Marketing, Faculty of Management Sciences, Rivers State University, Port Harcourt, Nigeria \\ Email: *nwokah.gladson@ust.edu.ng
}

How to cite this paper: Nwokah, N.G. and Briggs, J.T. (2017) Internal Marketing and Marketing Effectiveness of Hotel Industry in Rivers State. Journal of Human Resource and Sustainability Studies, 5, 238-257. https://doi.org/10.4236/jhrss.2017.54021

Received: October 14, 2017

Accepted: December 9, 2017

Published: December 12, 2017

Copyright $\odot 2017$ by authors and Scientific Research Publishing Inc. This work is licensed under the Creative Commons Attribution International License (CC BY 4.0).

http://creativecommons.org/licenses/by/4.0/ c) (i) Open Access

\begin{abstract}
The purpose of this study was to empirically investigate how Internal Marketing relates with Marketing Effectiveness in the Hotel Industry in Rivers State. The target population of this study is the twenty hotels listed under the Best Port Harcourt, Rivers State Hotel Specials and Deals of Tripadvisor online. Since, our study is organization based, key informants from the twenty hotels in Port Harcourt Rivers State, Nigeria constituted the sample of this study. The three key informants are: Customer relationship manager, marketing manager, and, food and beverages manager giving a total of hundred and twenty-five respondents who were administered the copies of the questionnaire. Upon retrieval and data cleaning, 100 copies were subjected to Data analysis. Data analyses were aided by the use of SPSS version 20.0 and hypotheses were tested using the Pearson Correlation Coefficient. After the data analysis, it was revealed that: Employee Job Satisfaction as a dimension of Internal Marketing relates very strongly and positively with Adequate Marketing Information, moderately and negatively with Customer Philosophy, and strongly and negatively with Adequate Strategic Orientation as measures of Marketing Effectiveness. We therefore concluded that there is a strong and positive relationship between Employee Job Satisfaction as a dimension of Internal Marketing and Adequate Marketing Information, moderate and negative relationship with Customer Philosophy and strong and negative relationship with Adequate Strategic Orientation as measures of Marketing Effectiveness. Based on the findings and conclusions we recommended that, in view of the fact that there exist a strong and positive relationship between Employee Job Satisfaction as a dimension of Internal Marketing and Adequate Marketing Information as a measure of Marketing Effectiveness, Hotel Industry in Rivers State should see that their physical facilities, equipment and communication materials are improved.
\end{abstract}

\section{Keywords}

Internal-Marketing, Marketing Effectiveness, Hotels, Rivers-State, Nigeria 


\section{Introduction}

Hotel services are services that meet hotel guest needs for accommodation, food and beverages, and additional services that are provided and for which payment is received in return. New social values on demand are vital to hotel industry employees, because different hotel guests display different lifestyles at different time and ways. Therefore, hotel marketers should center on service areas that creativity is obvious and shown in their individual associates and understanding between staff and guests. The employees of the hotel industry are in charge of carrying out the service process, resolving customer problems. Thus, it is important for the employees to be satisfied with their jobs and in turn satisfy the hotel guests [1]. Today internal marketing is one area manager face difficulty in terms of managing their employees. Sadly, research shows internal marketing has received little or no attention from scholars or managers [2]. Several studies on internal marketing have been carried out like that of [3]. They carried out their study in the United Kingdom. They used customer orientation and customer satisfaction, employee motivation and satisfaction, interfunctional coordination and integration, marketing-like approach to the above, and implementation of specific corporate or functional strategies to measure internal marketing. [4] measured internal marketing using: internal communication, staff training, job satisfaction, appraisals and feedbacks and customer consciousness.

Also many studies have been conducted on Marketing Effectiveness like that of [4] [5] [6]; used four basic dimensions to measure marketing effectiveness. They are Corporate, Competitive, Customers and Exogenous factors. [2] posited that marketing effectiveness has two components. They are adoption of the marketing concept and the implementation of the concept. According to [7], the measure of [8] [9] is seen as one of the best marketing effectiveness measures. Kotler used five components to measure marketing effectiveness. They are customer philosophy, integrated marketing organization, adequate marketing information, strategic orientation and operational efficiency. It is evident from the discussion above, that several studies in the area of Internal Marketing have been carried out [10] [11] [12] and also Marketing Effectiveness [8] [9] and that of [7]. Yet, despite all these studies something remains lacking. It is clear that no one in Rivers State, Nigeria that I know of have studied the relationship between Internal Marketing and Marketing Effectiveness. Limited research is done in this area, thus there is a considerable gap that exists in academic knowledge. But to fill this gap, we will concentrate our research on the hotel industry, which leads to new knowledge. The nexus between internal marketing and marketing effectiveness is an important one. The various dimensions of the internal marketing are likely to relate with the various measures of marketing effectiveness. The problem this research is designed to investigate is: How do the various dimensions of Internal Marketing relate with the various measures of Marketing Effectiveness? 


\section{Theoretical Framework}

\section{Social Exchange Theory (SET)}

The Social Exchange Theory (SET) as propounded in 1961 by George Homoms is based on the importance of negotiated exchanges in human relationship between parties (especially in workplace) involving communications, cost/benefits, alternative and obligations [13]. This theory focuses on the behavior of individual (social behavior) international which may result in social and economic outcomes in the market place [14]. The process of social exchange breads satisfaction when fair rewards are given in return or as benefits. Homoms ideal social exchange theory is governed by the belief of reinforcement principles built from the proposition of "success; stimulus; and deprivation-satiation". The application of Homoms social exchange theory is eminent in the building of the social structures of internal marketing to reward and satisfy the employees (internal customers) who would in turn reflect commitment and satisfaction in their job [15]. The social exchange theory is strong enough and hoped to illuminate, to offset interactive institutional barriers of a more complex organizational behavior and the effective management of internal customers. This theory no doubt is also a sure way and a new route to fulfilling the needs of the employees to be service-oriented in contact with external customers. Generally speaking, the adoption and development of social exchange theory in this research steams from the heels of employee motivation and job satisfaction for the provision of quality service when interfaced with customers. This informs the bass for adoption and application of this theory (SET) in this research as a contributor to organization-stakeholder relationship and relationship marketing.

\section{Concepts of Internal Marketing (IM)}

A 2012 review by Mousavi-Davoodi and Kaur argued that the concept of IM encompasses the employees, "the job as a product, which should satisfy the needs and requirements of customers" [16]. Internal marketing is also viewed from the perspective of internalization of the relationship amongst members at organizational levels creating service-oriented/customer-centric approach within employees to coming in contact with customers [17]. IM uses marketing approach to motivate employees who are viewed as internal customers [18], to produce a more customer-centric employees [17] [19]. According to Saeedinejad [20] internal marketing represents a comprehensive process of managing and merger of complex/multiple tasks of marketing within the business environment, equipping the employees and motivated to work. Indeed IM instills customer orientation among the employee by giving necessary support to enable teamwork among the organizations human resources [20] from attracting, developing, motivating and retention of key personnel in a conducive work environment. The IM process addresses problems associated with both effectiveness and efficiency of internal services, customer orientation, market orientation, and implementation of programmes and routines [21]. 
In fact, IM is the market orientation which adopts marketing principle in the organization with the aim to establish company's values [22]. This definition certainly is inclusive of activities which enhances internal communication chain and a host of cross-functional coordination to institute an effective marketing performance [23].

Internal marketing was posited first as a key to the problem of consistently delivering high quality service [24]. Employees are seen as customer, their jobs as internal products and the organization endeavours to offer jobs. Nevertheless, in spite of this, very few organisations in reality put into practice the concept.

[25] posited internal marketing as inward turning of traditional marketing techniques. Also, [26] [27] saw internal marketing as to attract, develop, motivate and retain employees that are competent through job-products that satisfy their needs. [28] defined internal marketing as using a marketing perspective to manage human resources of an organisation. Furthermore, [20] defined internal marketing as the work organisation performed in terms of training and motivating its internal market to work as a team to satisfy their external customers.

\section{Dimensions of Internal Marketing}

[4] posited that effective internal marketing will lead to effective external marketing. According to him internal marketing begins with the thought that employees of the organisation are the first market.

[28] measured internal marketing using: internal communication, staff training, job satisfaction, appraisals and feedbacks and customer consciousness. Also, [7] carried out a research in the United Kingdom. They measured Internal Marketing using employee motivation and employee satisfaction, customer orientation and customer satisfaction, interfunctional coordination and integration, marketing-like approach to the above and the implementation of specific functional strategies.

\subsection{Employee Job Satisfaction}

Employee Job satisfaction is the employees feelings they have about their job [29]. Gounaris (2008) argued that employees' satisfaction shows on the external customers' consequential increased profitability. He saw employee job satisfaction as pleasurable or positive emotional state resulting from one's evaluation of job experiences.

The nature of job satisfaction shows that employee is likely to continue with a job that is satisfying and leave a job which is dissatisfying.

\subsection{Interfunctional Coordination}

Interfunctional coordination involves the coordination of the organizations employees and other resources to create superior customer value [11]. According to Kohli \& Jaworski (1990), marketing is not the task of a marketing department alone but the coordination of all other departments to create superior customer 
value. [12] [15] [17] posited that internal marketing sees employees as internal customers. [21] argued that the coordination of the different functions of the organisation results in greater efficiency. Marketing requires inter-departmental teamwork and information sharing and resources. [23] saw interfunctional coordination as teamwork between the diverse departments in the organisation. Interfunctional coordination allows an organisation to exchange information efficiently among its internal units. That is, it captures the tendency of different departments to hold different and contradictory views and put away functional interests for the benefit of the entire organisation. According to them all departments in the organization ought to be responsive to all other department's needs.

\section{Concept of Marketing Effectiveness}

Marketing effectiveness concept first came into existence in the 1990s. According to [30] marketing effectiveness posited that managers should have adequate information and distributes appropriate resources to different market. [18] asserted, the original obligation of marketing effectiveness is that managers must identify the primacy of studying the market, distinguish the several opportunities, select the best market to serve and offer superior customer value to satisfy their needs and wants. Furthermore, [5] argued that organisations that have the marketing effectiveness is high are those that are close to their consumers, have a common set of values and also demonstrate an external market orientation. [31] agree that companies with high marketing effectiveness operate better when compared with companies that do not have. The competitive environment of business today demands that for organization to be successful to move forward in its selected market segment, there must be implementation of marketing.

The marketing effectiveness concept has drawn increased attention among academic researchers and business practitioners over the years [31] [32] [33] posited that only a few organizations completely practice refined marketing. Ultimately, marketing effectiveness differentiate the amateur from the expert in the global market [18].

\section{Measures of Marketing Effectiveness}

Researchers have conducted empirical investigations on marketing effectiveness like the study of [5] [8] [12] and [34]. According to them there are four dimensions of marketing effectiveness: Corporate, Competitive, Customers and Exogenous factors. [32] posited that the operationalisation of [14] [18] is seen as one of the best measures of marketing effectiveness. Kotler in his study stated a combination of five component: customer philosophy, integrated marketing organization, adequate marketing information, strategic orientation and operational efficiency.

\subsection{Customer Philosophy}

Consumer's philosophy according to [18] is the external center of attention of 
the organization on the consumer needs and wants and how to monitor the satisfaction of consumers by carrying out consumer's surveys. Some managers are product-oriented (make good product and sell). Some managers are technologyoriented (get latest technologies and are not interested in the size or customers wants). Some are sales-oriented (get sufficient sales effort and anything can be sold). An organisation is on its way to effective marketing when it begins with the consumer when designing its structure, plans and control.

\subsection{Adequate Marketing Information}

Studies have shown that businesses that fail have not obtain and acted upon market information in regards to their product or service [34]. Organization without adequate marketing information will not be able to take adequate business decisions [32]. Thus, executives of the organization need sufficient information to plan and allocate resources correctly to diverse markets [18]. The task of information in decision in marketing cannot be challenge bearing in mind that marketing success of the organization depends on the availability and the accuracy of marketing information.

According to [35] marketing encompass all operations (market research, product selection and design, advertising, pricing) from moving goods and services from point of production to the ultimate users.

\subsection{Strategic Orientation}

Strategic Orientation is a definite way to build up strategies based on the analysis of strengths, weaknesses, opportunities and threats. It generates a number of rational alternatives and provides a prioritisation. Strategic Orientation combines internal analysis of a project (Strengths and Weaknesses) with an external analysis (Opportunities and Threats) to arrive at strategic options from which a choice can be made [32]. Therefore, in order to have a sound SWOT analysis of internal and external resources and the function of the organization, the environment needs to be scanned and the institutional setting needs to be analysed.

Marketing effectiveness rely on management design of a strategy that is profitable out of its philosophy, organization, and information resources [32].

\section{Internal Marketing and Marketing Effectiveness}

Internal marketing is vital in increasing organization that is marketing-oriented. In application, internal marketing is concerned above all with communicating, increasing responsiveness, responsibility and unity of purpose. It intend at developing internal and external customer consciousness. According to [35], internal marketing influences the effectiveness of marketing and external marketing programmes.

\subsection{Employee Job Satisfaction and Marketing Effectiveness}

[6] posited that, when employees needs are met it motivates them and make them 
to remain in the organization and as a result increase their satisfaction and in so doing increase marketing effectiveness and thus increases the possibility of generating external customer satisfaction and loyalty. Satisfaction suggested a more reciprocal relationship with marketing effectiveness [32]. In general, employees that are satisfied are likely to be more customer-oriented and thus deliver better customer service [35]. The relationship between job satisfaction and customer philosophy study has been carried out by several authors [36]. Their findings showed higher levels of job satisfaction leads to higher degrees of customer philosophy.

On the other hand, [31] connects job satisfaction to supervision, adequate marketing information and physical work conditions. Also, [7] concluded that the quality of leader-member exchange mediated positive relationships between a strategic orientation and leader-rated in-role job performance, leader-rated innovative job performance, and job satisfaction. [10], found that strategic orientation strongly relate with employees' job satisfaction and organizational commitment. Thus, the following hypotheses were proposed.

$\mathrm{Ho}_{1}$ There is no significant relationship between Employee Job Satisfaction and Customer Philosophy.

$\mathrm{Ho}_{2}$ There is no significant relationship between Employee Job Satisfaction and Adequate Marketing Information.

$\mathrm{Ho}_{3}$ There is no significant relationship between Employee Job Satisfaction and Strategic Orientation.

\subsection{Interfunctional Coordination and Marketing Effectiveness}

The literature documents the positive relationship between Interfunctional Coordination and marketing effectiveness [15] [18] [19] posited that interfunctional coordination is very important to the orgaanisation. Their findings suggested that interfunctional coordination is significantly and positively related to marketing information systems. Also, [19] in their research found out that interfunctional coordination relates to the company's internal climate of marketing effectiveness. Furthermore, Mohammad et al [22], results show that correlation coefficient between the elements of interfunctional coordination and marketing effectiveness is equal. Thus research hypothesis is confirmed and there is significant relationship between interfunctional coordination and effectiveness of company in market. Thus, the following hypotheses were proposed:

$\mathrm{Ho}_{4}$ There is no significant relationship between Interfunctional Coordination on Customer Philosophy.

$\mathrm{Ho}_{5}$ There is no significant relationship between Interfunctional Coordination on Adequate Marketing Information.

$\mathrm{Ho}_{6}$ There is no significant relationship between Interfunctional Coordination on Strategic Orientation.

\section{Operational Framework}

Figure 1 depicts the researcher's operationalization of the relationships that exist 


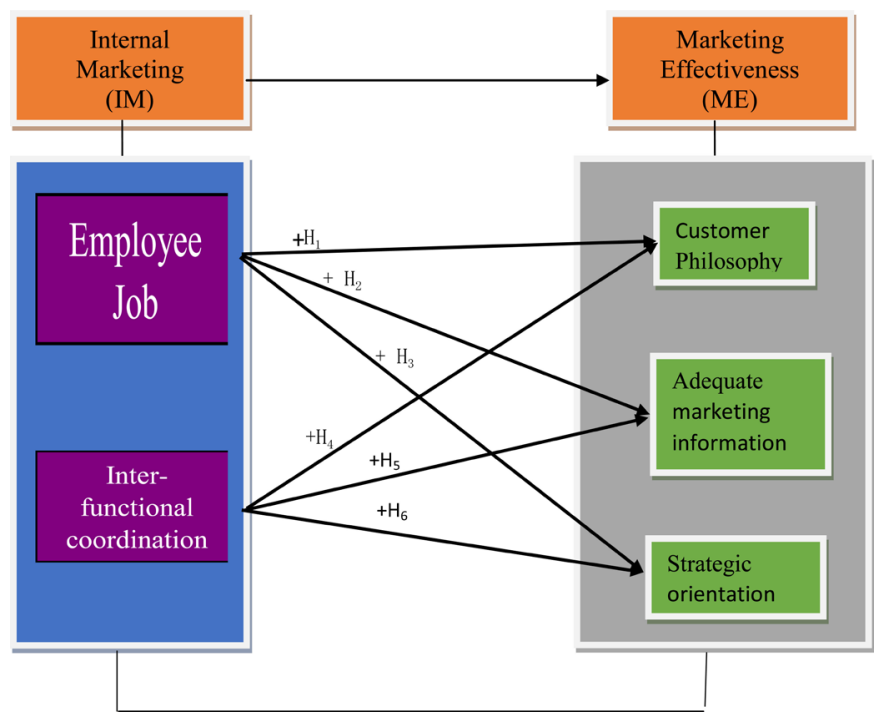

Figure 1. Operational Framework on the relationship between Internal Marketing and Marketing Effectiveness in Hotel industry in Rivers State.

amongst the variables.

\section{Research Design}

This hypothesis testing study adopted a causal investigation to establish a relationship between Internal Marketing and Marketing Effectiveness of Hotel Industry in Rivers State. The researcher did not manipulate or interfered into the variables under study. The choice of research design is likely to be influenced, as [36] noted, by purpose of the study, study setting, and unit of analysis of the study. Considering all these, the cross sectional survey research design in a noncontrived (normal or natural) setting (Hotel firms) was adopted. According to [36], the survey research design offers a wide coverage and permits generalizability of research findings. The cross sectional study involves a study at a single time.

\subsection{Sample and Sampling Procedure}

There are twenty hotels in Port Harcourt whose presence is found online. Thus, the target population in this study is the twenty hotels listed under the Best Port Harcourt, Rivers State Hotel Specials and Deals of Tripadvisor online. Since, our study is organization based, key informants from the twenty hotels in Port Harcourt Rivers State, Nigeria constituted the sample of this study. The five key informants are: Customer relationship manager, marketing manager, food and beverages manager, front office managers, and sales manager giving a total of hundred respondents. The study made use of the primary sources of data (questionnaire) and secondary sources of data (documentary from the mobile networks, internet and library research). The main data collection instrument is the questionnaire. The questionnaire for this study was divided into two sections. The first part generated demographic data while the second part generated data 
on internal marketing and marketing effectiveness. The questions in part B - D was designed using the 5-point Likert scale (ordinal scale). The copies of the questionnaire were administered to five key informants-Customer relationship manager, marketing manager, food and beverages manager, front office managers, and sales manager of each of the twenty hotels listed under the Best Port Harcourt, Rivers State Hotel Specials and Deals of Tripadvisor online giving a total of one hundred respondents.

\subsection{Reliability and Validity of Research Instrument}

It is important that at every stage of a research study a reliability and validity test be conducted. Reliability is when the instrument measures what it is meant to measure consistently. Also validity as when the research instrument measures what it is meant to measure. The measuring instrument was given face validity by senior academics within Rivers State University who were given the questionnaire for vetting. With this the final questionnaire was drawn. According to [36] the Cronbach Alpha is a good reliability coefficient to prove how fit items in a questionnaire set are interrelated. The Cronbach Alpha Coefficient from the Statistical Package of Social Sciences was also used to test the instrument. See Table 1.

The Reliability of the research instrument with the help of SPSS revealed a very high reliability coefficient for the two variables tested. The results as shown in Table 1 falls within the standard range of 0.7 set by Nunnally [36]. 5 items were used to measure Internal Marketing and the Cronbach's Alpha co-efficient of the SPSS output recorded 0.9 meaning there is a correlation amongst the items. Also, 11 items were used to measure Marketing Effectiveness and the Cronbach's Alpha co-efficient of the SPSS output recorded 0.9 meaning there is a correlation amongst the items in the questionnaire.

\section{Findings}

\subsection{Responses from Descriptive Statistics}

\section{Employee Job Satisfaction as a Dimension of Internal Marketing}

The items of the dimensions of internal marketing are assessed with the mean and standard deviations. Table 2 shows Employee Job Satisfaction as a Dimension of Internal Marketing.

As can be seen in Table 2, it appears that hotel workers are very comfortable working in their various places of work as the statistical evidence shown in Table 2 shows that hotel employees see their work as positive or pleasurable with

Table 1. Reliability test results.

\begin{tabular}{cccc}
\hline S/No. & Variables & Number of Items & Cronbach's Alpha \\
\hline 1 & Internal Marketing (IM) & 5 & 0.9 \\
2 & Marketing Effectiveness (ME) & 11 & 0.9 \\
\hline
\end{tabular}

Source: SPSS Output. 
Table 2. Employee job satisfaction as a dimension of internal marketing.

\begin{tabular}{clcc}
\hline S/No. & \multicolumn{1}{c}{ Employee Job Satisfaction } & Mean $-\chi$ & Std Dev s \\
\hline 1 & The hotel employees see their work as positive or pleasurable. & 5.00 & 0.00 \\
2 & The hotel employees feel a sense of belongings for the organization. & 4.00 & 0.00 \\
3 & $\begin{array}{l}\text { There are opportunities for career development and the pay scale } \\
\text { gives satisfaction. }\end{array}$ & 3.47 & 0.502 \\
\hline
\end{tabular}

Source: SPSS Output. KEY: $\_$= Mean score; $\mathrm{s}=$ Standard deviation.

Table 3. Inter-functional coordination as a dimension of internal marketing.

\begin{tabular}{clcc}
\hline S/No. & \multicolumn{1}{c}{ Inter-functional Coordination } & Mean $\_$ & Std Dev s \\
\hline $1 \quad \begin{array}{l}\text { The hotel is involved in the coordination of personnel and other } \\
\text { resources all through the firm to create superior customer value. }\end{array}$ & 3.65 & 0.480 \\
& $\begin{array}{l}\text { The marketing information of the hotel is made known to other } \\
\text { departments and all are concerned in business plans/strategies } \\
\text { preparation. }\end{array}$ & 4.16 & 1.226 \\
\hline
\end{tabular}

Source: SPSS Output.

the highest mean of 5.00 with 0.000 standard deviation. This is followed by the respondents' confirmation that their hotels employees feel a sense of belongings for their organization. The statistical evidence in Table 2 confirms this with a mean of 4.00 and a standard deviation of 0.00 .

\subsection{Inter-Functional Coordination as a Dimension of Internal Marketing}

Table 3 shows Inter-functional coordination as a Dimension of Internal Marketing.

As can be seen in Table 3, it appears that marketing information of the hotel is made known to other departments and all are concerned in business plans/ strategies preparation as the statistical evidence shown in Table 3 with the highest mean of 4.16 and with 1.226 standard deviation.

\subsection{Customer Philosophy as a Measure of Marketing Effectiveness}

The indices to measure the dependent variables (Marketing effectiveness) were also assessed. Customer philosophy as a measure of marketing effectiveness was measured with four items.

As can be seen in Table 4, hotel management encouragement of word of mouth communication, customer orientation and placement of importance on business image appear to contribute more as an indicator of customer philosophy as a measure of marketing effectiveness with a standard deviation of 1.100 and mean value of 3.46. This is followed by management in planning its organization takes note of its customers, suppliers, competitors, and its working environment. This scored a mean of 3.02 and a standard deviation of 1.178 . 
Table 4. Customer philosophy as a measure of marketing effectiveness.

\begin{tabular}{clcc}
\hline S/No. & \multicolumn{1}{c}{ Customer Philosophy } & Mean $\chi$ & Std Dev s \\
\hline $1 \quad \begin{array}{l}\text { The management of the hotel promotes communication through } \\
\text { word of mouth, customer orientation and placement of importance } \\
\text { on business image. }\end{array}$ & 3.46 & 1.100 \\
& $\begin{array}{l}\text { The hotel management recognizes that to design or provide } \\
\text { products/services is vital to serve needs and wants of customer and } \\
\text { create diverse strategies for the diverse market segments. }\end{array}$ & 2.27 & 0.867 \\
$3 \quad \begin{array}{l}\text { In planning its organization, management takes note of its } \\
\text { customers, suppliers, competitors, and its working environment. }\end{array}$ & 3.02 & 1.178 \\
$4 \quad \begin{array}{l}\text { Management recognizes the dominance of the market situation and } \\
\text { customers' needs and wants to shape their plans and processes. }\end{array}$ & 2.18 & 0.734 \\
\hline
\end{tabular}

Source: SPSS Output.

Table 5. Adequate marketing information as a measure of marketing effectiveness.

\begin{tabular}{clcc}
\hline S/No. & \multicolumn{1}{c}{ Adequate Marketing Information } & Mean $\_$ & Std Dev s \\
\hline $1 \quad \begin{array}{l}\text { A lot of effort is spent on measuring the cost-effectiveness of } \\
\text { diverse marketing expenditures }\end{array}$ & 4.00 & 0.000 \\
$2 \quad \begin{array}{l}\text { The management of the hotel knows the potential of sales and } \\
\text { profitability of the diverse segments of the market. }\end{array}$ & 4.96 & 0.141 \\
$3 \quad \begin{array}{l}\text { Quality information is received by management to conduct } \\
\text { effective marketing. }\end{array}$ & 4.45 & 0.500 \\
\hline
\end{tabular}

Source: SPSS Output.

\subsection{Adequate Marketing Information as a Measure of Marketing Effectiveness}

Adequate Marketing Information as a measure of Marketing Effectiveness was measured with three items.

As can be seen in Table 5, hotel management understanding of the potential of sales and profitability of the diverse segments of the market appear to contribute more as an indicator of Adequate Marketing Information as a measure of marketing effectiveness with a standard deviation of 0.141 and mean value of 4.96 . This is followed by quality information is received by management to conduct effective marketing. This scored a mean of 4.45 and a standard deviation of 0.500 .

\section{Testing of Research Hypotheses}

This section is aimed at testing the six hypotheses stated in chapter one of this dissertation. Since the descriptive analysis showed a normal distribution of the dependent and independent variables, the Pearson moment correlation is used to run parametric analysis. This is intended to recognize the nature of the relationship between the dimensions

\subsection{Relationship between Employee Job Satisfaction and Customer Philosophy}

In chapter one of this research work, it was hypothesized that there is no signifi- 
cant relationship between Employee Job Satisfaction and Customer Philosophy. Table 6 shows the statistical evidence of the relationship between these variables.

The statistical evidence in Table 6 suggests a moderate and negative relationship between Employee Job Satisfaction and Customer Philosophy with $-0.379^{* *}$ Pearson correlation coefficient at 0.01 significant levels. This does not support hypothesis one $\left(\mathrm{H}_{1}\right)$, that there is no relationship between Employee Job Satisfaction and Customer Philosophy.

\subsection{Relationship between Employee Job Satisfaction and Adequate Marketing Information}

In chapter one of this research work, it was hypothesized that there is no significant relationship between Employee Job Satisfaction and adequate marketing information.

The statistical evidence in Table 7 suggests a very strong and positive relationship between Employee Job Satisfaction and Adequate Marketing Information with $0.931^{\star *}$ Pearson correlation coefficient at 0.01 significant levels. This again does not agree with hypothesis two $\left(\mathrm{H}_{2}\right)$, that there is no relationship between Employee Job Satisfaction and adequate marketing information.

\subsection{Relationship between Employee Job Satisfaction and Strategic Orientation}

In chapter one of this research work it was hypothesized that there is no significant relationship between relationship between Employee Job Satisfaction and Strategic Orientation.

The statistical evidence in Table 8 suggests a strong and negative relationship

Table 6. Relationship between Employee Job Satisfaction and Customer Philosophy ( $\mathrm{n}=$ 100).

\begin{tabular}{cccc}
\hline Variables & Pearson Correlation & $\begin{array}{c}\text { Employee Job } \\
\text { Satisfaction }\end{array}$ & $\begin{array}{c}\text { Customer } \\
\text { Philosophy }\end{array}$ \\
\hline Employee Job Satisfaction & Sig. (2-tailed) & 1 & $-0.379^{* *}$ \\
Customer Philosophy & Pearson Correlation & $-0.379^{* *}$ & 0.00 \\
& Sig. (2-tailed) & 0.00 & 1 \\
\hline
\end{tabular}

**: Correlation is significant at the 0.01 level (2-tailed).

Table 7. Relationship between Employee Job Satisfaction and Adequate Marketing Information $(\mathrm{n}=100)$.

\begin{tabular}{cccc}
\hline Variables & & $\begin{array}{c}\text { Employee Job } \\
\text { Satisfaction }\end{array}$ & $\begin{array}{c}\text { Adequate Marketing } \\
\text { Information }\end{array}$ \\
\hline Employee Job Satisfaction & $\begin{array}{c}\text { Pearson Correlation } \\
\text { Sig. (2-tailed) }\end{array}$ & 1 & $0.931^{\star *}$ \\
Adequate marketing information & $\begin{array}{c}\text { Pearson Correlation } \\
\text { Sig. (2-tailed) }\end{array}$ & $0.931^{\star *}$ & 0.00 \\
& 0.00 & 1 \\
\hline
\end{tabular}

${ }^{* *}$ : Correlation is significant at the 0.01 level (2-tailed). 
Table 8. Relationship between Employee Job Satisfaction and Strategic Orientation $(\mathrm{n}=$ 100).

\begin{tabular}{cccc}
\hline Variables & & $\begin{array}{c}\text { Employee Job } \\
\text { Satisfaction }\end{array}$ & Strategic Orientation \\
\hline Employee Job Satisfaction & $\begin{array}{c}\text { Pearson Correlation } \\
\text { Sig. (2-tailed) }\end{array}$ & 1 & $-0.773^{* *}$ \\
Strategic Orientation & Pearson Correlation & $-0.773^{* *}$ & 0.00 \\
& Sig. (2-tailed) & 0.00 & 1 \\
\hline
\end{tabular}

**: Correlation is significant at the 0.01 level (2-tailed).

Table 9. Relationship between inter-functional coordination and customer philosophy (n $=100)$.

\begin{tabular}{cccc}
\hline Variables & & $\begin{array}{c}\text { Inter-functional } \\
\text { Coordination }\end{array}$ & Customer Philosophy \\
\hline Employee Job Satisfaction & $\begin{array}{c}\text { Pearson Correlation } \\
\text { Sig. (2-tailed) }\end{array}$ & 1 & 0.023 \\
Customer Philosophy & Pearson Correlation & 0.023 & 0.00 \\
& Sig. (2-tailed) & 0.00 & 1 \\
\hline
\end{tabular}

**: Correlation is not significant at the 0.01 level (2-tailed).

between Employee Job Satisfaction and adequate Strategic Orientation with $-0.773^{* *}$ Pearson correlation coefficient at 0.01 significant levels. This is not in line with hypothesis three $\left(\mathrm{H}_{3}\right)$, that there is no relationship between Employee Job Satisfaction and Strategic Orientation.

\subsection{Relationship between Inter-Functional Coordination and Customer Philosophy}

In chapter one of this research work, it was hypothesized that there is no significant relationship between Inter-functional Coordination and Customer Philosophy.

The statistical evidence in Table 9 suggests no significant relationship between Inter-functional Coordination and Customer Philosophy with 0.023 Pearson correlation coefficient at 0.01 significant levels. This supports hypothesis four $\left(\mathrm{H}_{4}\right)$, that there is no relationship between Inter-functional Coordination and Customer Philosophy.

\subsection{Relationship between Inter-Functional Coordination and Adequate Marketing Information}

In chapter one of this research work, it was hypothesized that there is no significant relationship between Inter-functional Coordination and adequate marketing information.

The statistical evidence in Table 10 suggests a strong and negative relationship between Inter-functional Coordination and adequate marketing information with $-0.753^{\star *}$ Pearson correlation coefficient at 0.01 significant levels. This 
Table 10. Relationship between Inter-functional Coordination and Adequate Marketing Information $(\mathrm{n}=100)$.

\begin{tabular}{cccc}
\hline Variables & & $\begin{array}{c}\text { Employee Job } \\
\text { Satisfaction }\end{array}$ & $\begin{array}{c}\text { Adequate marketing } \\
\text { information }\end{array}$ \\
Employee Job Satisfaction & $\begin{array}{c}\text { Pearson Correlation } \\
\text { Sig. (2-tailed) }\end{array}$ & 1 & $-0.753^{* *}$ \\
Adequate marketing information & $\begin{array}{c}\text { Pearson Correlation } \\
\text { Sig. (2-tailed) }\end{array}$ & $-0.753^{* *}$ & 0.00 \\
& 0.00 & 1 \\
\hline
\end{tabular}

${ }^{*}$ : Correlation is significant at the 0.01 level (2-tailed).

Table 11. Relationship between inter-functional coordination and strategic orientation ( $\mathrm{n}$ $=100)$.

Variables

Inter-functional Coordination
Strategic Orientation
Inter-functional
Coordination

Strategic Orientation

$\begin{array}{cc}1 & 0.600^{\star *} \\ & 0.00 \\ 0.600^{\star *} & \\ 0.00 & 1\end{array}$

${ }^{*}$ : Correlation is significant at the 0.01 level (2-tailed).

again is not in line with hypothesis five $\left(\mathrm{H}_{5}\right)$, that there is no relationship between Inter-functional Coordination and adequate marketing information.

\subsection{Relationship between Inter-Functional Coordination and Strategic Orientation}

In chapter one of this research work, it was hypothesized that there is no significant relationship between Inter-functional Coordination and Strategic Orientation.

The statistical evidence in Table 11 suggests a strong and positive relationship between Inter-functional Coordination and Adequate Strategic Orientation with $0.600^{* *}$ Pearson correlation coefficient at 0.01 significant levels. This again does not agree with hypothesis three $\left(\mathrm{H}_{6}\right)$, that there is no relationship between Interfunctional Coordination and Strategic Orientation.

\section{Discussion of Findings}

The aim of this section is to discuss the findings from this study.

\subsection{Employee Job Satisfaction and Marketing Effectiveness}

The finding of this study suggests a moderate and negative relationship between Employee Job Satisfaction and Customer Philosophy. This does not corroborate with previous study. Several studies like the studies of [15] [22] have been carried out on the relationship between Employee Job Satisfaction and Customer Philosophy. Their findings showed that when employee job satisfaction level is high, it encourages them to have higher Customer Philosophy. Also, when in- 
ternal marketing i.e. practice effectively in the organization, it leads to effective marketing and external marketing [13]. According to [19], when employees needs are fulfilled it motivates them and encourages them to remain in the organization and thereby leads to higher marketing effectiveness and also possible external customer satisfaction and loyalty.

Satisfaction suggested a more reciprocal relationship with marketing effectiveness [25]. The result of their findings corroborates with this study finding. This study finding suggests a very strong and positive relationship between Employee Job Satisfaction and Adequate Marketing Information. Also, [16] concluded that the leader-member quality of exchange relates positively between Strategic Orientation and leader-rated job performance and satisfaction of their job. [22], found that Strategic Orientation strongly relate with employees' job attitudes. This does not support the study finding. The study finding suggests a strong and negative relationship between Employee Job Satisfaction and adequate Strategic Orientation.

\subsection{Interfunctional Coordination and Marketing Effectiveness}

The literature documents the positive relationship between Interfunctional Coordination and Marketing Effectiveness [23] [30]. This does not agree with the finding of this study. The finding of this study suggests no significant relationship between Inter-functional Coordination and Customer Philosophy. [22] in their study suggested that interfunctional coordination is related significantly and positively with effectiveness of marketing information systems. This does not corroborates with this study finding which suggested a strong and negative relationship between Inter-functional Coordination and Adequate Marketing Information. The study finding indicates a strong and positive relationship between Inter-functional Coordination and Adequate Strategic Orientation. This corroborates with the findings of [20]. In their research, they found out that interfunctional coordination relates more with company's marketing effectiveness. Furthermore, [1], results show that correlation coefficient between the elements of interfunctional coordination and marketing effectiveness is equal.

\section{Summary of Findings}

The previous chapter presented data on Internal Marketing and Effectiveness, and the interaction between them (test of hypotheses) and discussion of findings. In this chapter the findings were summarized, conclusions drawn and recommendations made.

1) We observed that Employee Job Satisfaction relates very strongly and positively with Adequate Marketing Information.

2) Employee Job Satisfaction relates moderately and negatively with Customer Philosophy.

3) The finding of this study revealed a strong and negative relationship between Employee Job Satisfaction and Adequate Strategic Orientation. 
4) The finding of this study suggests no significant relationship between Interfunctional Coordination and Customer Philosophy.

5) We observed that Inter-functional Coordination has a strong and negative relationship with Adequate Marketing Information.

6) The finding of this study revealed a strong and positive relationship between Inter-functional Coordination and Adequate Strategic Orientation.

\section{Conclusions}

This study examined the relationship between Internal Marketing and Marketing Effectiveness of Hotel Industry in Rivers State. Based on the findings of this study, the following conclusions were drawn:

1) There is a strong and positive relationship between Employee Job Satisfaction and Adequate Marketing Information.

2) There is a moderate and negative relationship between Employee Job Satisfaction as a dimension of Internal Marketing and Customer Philosophy.

3) Employee Job Satisfaction has a strong and negative relationship with Adequate Strategic Orientation.

4) There is a strong and negative relationship between Inter-functional Coordination as a dimension of Internal Marketing and Adequate Marketing Information as a measure of Marketing Effectiveness.

5) There is no significant relationship between Inter-functional Coordination and Customer Philosophy.

6) Inter-functional Coordination has a strong and positive relationship with Adequate Strategic Orientation.

\section{Recommendations}

Recommendations were made based on the findings and conclusions of this study:

1) In view of the fact that there exist a strong and positive relationship between Employee Job Satisfaction as a dimension of Internal Marketing and Adequate Marketing Information as a measure of Marketing Effectiveness, and also a moderate and negative relationship between Employee Job Satisfaction and Customer Philosophy, and further a strong and negative relationship between Employee Job Satisfaction as a dimension of Internal Marketing and Adequate Strategic Orientation, Hotel Industry in Rivers State should see that their physical facilities, equipment and communication materials are improved. Make available carrier opportunities for development and employees satisfaction should be evaluated regularly with their job the condition to identify if they take pleasure in and sees their job as satisfying.

2) Since Inter-functional Coordination has a strong and negative relationship with Adequate Marketing Information as a measure of Marketing Effectiveness, also there exist no significant relationship between Inter-functional Coordination and Customer Philosophy and further Inter-functional Coordination has a 
strong and positive relationship with Adequate Strategic Orientation, Hotel Industry in Rivers State should be concerned in personnel and other resources coordination all through the organisation to create superior customer value. They should see to it that marketing information of the hotel is made known to other departments and all departments are concerned in business plans/strategies preparation.

\section{Contribution to Knowledge}

There have been several studies on Internal Marketing and Marketing Effectiveness but none that I know of have written on Internal Marketing and Marketing Effectiveness of Hotel Industry in Rivers State. The present study fills this void by analyzing Internal Marketing and Marketing Effectiveness of Hotel Industry in Rivers State.

The researcher proposes a model of the relationship between Internal Marketing and Marketing Effectiveness of Hotel Industry in Rivers State based on the findings from the study, as shown in Figure 2. This model proposes that there is Strong, Moderate, Weak, Negative and no relationship between Internal Marketing and Marketing Effectiveness.

\section{Heuristic Model}

The diagram below depicts the Heuristic model of the relationships that exist

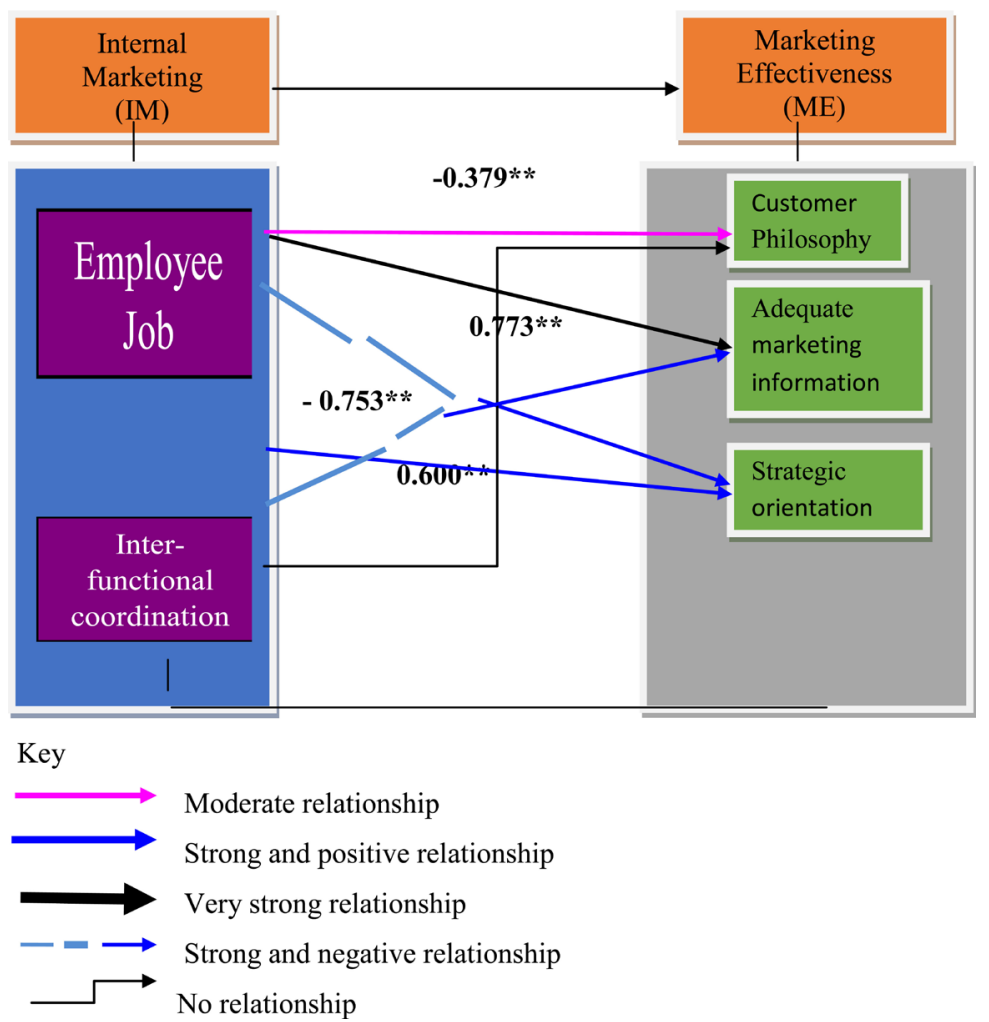

Figure 2. Heuristic model of internal marketing and marketing effectiveness of hotel industry in Rivers State. 
amongst the variables.

The Employee Job Satisfaction has a very strong and positive relationship with Adequate Marketing Information measure of Marketing Effectiveness of Hotel Industry in Rivers State. The black arrow indicates very strong relationship. Also, the Employee Job Satisfaction has a moderate and negative relationship with Customer Philosophy as depicted by the pink marrow. Further, there exist a strong and negative relationship between Employee Job Satisfaction and Adequate Strategic Orientation as shown by the blue broken arrow. Inter-functional Coordination has no significant relationship with Customer Philosophy as shown by the curved arrow. Also, Inter-functional Coordination has a strong and negative relationship with Adequate Marketing Information as indicated by the blue broken arrow. Finally, a strong and positive relationship exists between Inter-functional Coordination and Adequate Strategic Orientation as depicted by the blue arrow.

\section{References}

[1] Rafiq, M. and Ahmed, P.K. (1993) The Scope of Internal Marketing: Defining the Boundary Marketing and Human Resource Management. Journal of Marketing Management, 9, 219-232. https://doi.org/10.1080/0267257X.1993.9964234

[2] Boris, B., Donald, R.C. and Schinder, P.S. (2005) Business Research Methods. McGraw-Hill Education.

[3] Nwokah, N.G. and Ahiauzu, A.I. (2008) Managerial Competency and Marketing Effectiveness in Corporate Organizations in Nigeria. Journal of Management Development, 27, 858-878. https://doi.org/10.1108/02621710810895677

[4] Norburn, D., Birley, S. and Dunn, M.G. (1988) Strategic Marketing Effectiveness and Its Relationship to Corporate Culture and Beliefs: A Cross-National Study. International Studies of Management and Organization, 18, 83-100. https://doi.org/10.1080/00208825.1988.11656481

[5] Nwokah, N.G. (2006) Marketing Effectiveness and Business Performance. Nigerian Journal of Business and Society, 3, 15-26.

[6] Rafiq, M. and Ahmed, P.K. (2000) Advances in the Internal Marketing Concept: Definition, Synthesis and Extension. Journal of Services Marketing, 6, 449-462. https://doi.org/10.1108/08876040010347589

[7] Slater, S. and Narver, J. (1994) Does Competitive Environment Moderate the Market Orientation Performance Relationship? Journal of Marketing, 58, 46-55. https://doi.org/10.2307/1252250

[8] Sultan, M.S. (2012) The Role of Marketing Information System in Marketing Decision-Making in Jordanian Share-Holding Medicines Production Companies. IJRRAS, 11, 326-336.

[9] Tansuhaj, P., Wong, J. and McCullough, J. (1987) Internal and External Marketing: Effects on Consumer Satisfaction in Banks in Thailand. International Journal of Bank Marketing, 5, 73-83. https://doi.org/10.1108/eb010812

[10] Saeedinejad, M.M. (2016) The Study of the Effective of Internal Marketing on Sales Staff Performance with an Emphasis on the Role of Organizational Commitment. Asian Social Sciences, 12, 169-178. https://doi.org/10.5539/ass.v12n6p169

[11] Sanzo, M.J., Santos, M.L., Vázquez, R. and Álvarez, L.I. (2003) The Effect of Market 
Orientation on Buyer-Seller Relationship Satisfaction. Industrial Marketing Management, 32, 327-345. https://doi.org/10.1016/S0019-8501(01)00200-0

[12] Tay, J.Y. and Tay, L. (2007) Market Orientation and the Property Development Business in Singapore. International Journal of Strategic Property Management, 11, $1-16$.

[13] Tiny, A. (2012) Implementation of Internal Marketing on a Sample of Egyptian Five-Star Hotels. Anatolia-An International Journal of Tourism and Hospitality Research, 22, 153-167.

[14] Trochim, W. (2006) The Research Methods Knowledge Base. Atomic Dog Pub., Cincinnati.

[15] Webster, C. (1995) Marketing Culture and Marketing Effectiveness in Service Firms. Journal of Services Marketing, 9, 6-21. https://doi.org/10.1108/08876049510085973

[16] Yukselen, C. (1997) Factors Associated with Marketing Effectiveness of Small and Medium Sized Firms in Turkey. International Journal of Commerce and Management, 7, 99-105. https://doi.org/10.1108/eb047351

[17] Zeithaml, V.A., Parasuraman, A. and Berry, L.L. (1990) Delivering Quality Service: Balancing Customer Perceptions and Expectations. The Free Press, New York.

[18] Zhou, K.Z., Gao, G.Y., Yang, Z. and Zhou, N. (2005) Developing Strategic Orientation in China: Antecedents and Consequences of Market and Innovation Orientations. Journal of Business Research, 58, 1049-1058. https://doi.org/10.1016/j.jbusres.2004.02.003

[19] Zikmund, W.G. (2004) Business Research Methods. Forth Work, Dryden Press.

[20] Riketta, M. (2012) The Causal Relation between Job Attitudes and Performance: A Meta-Analysis of Panel Studies. Journal of Applied Psychology, 93, 472-481. https://doi.org/10.1037/0021-9010.93.2.472

[21] Pettijohn, C.E., Pettijohn, L.S. and Taylor, A.J. (2007) Does Salesperson Perception of the Importance of Sales Skills Improve Sales Performance, Customer Orientation, Job Satisfaction? Journal of Personal Selling and Sales Management, 27, 75-88. https://doi.org/10.2753/PSS0885-3134270105

[22] Papasolomou, D.I. (2002) The Role of Employee Development in Customer Relations: The Case of UK Retail Banks. Corporate Communications: An International Journal, 7, 62-76. https://doi.org/10.1108/13563280210416053

[23] Okwandu, G.A. (2004) Research Methods in Business and Social Sciences. Civincs Pub., Owerri.

[24] Oosthuizen, H. (1992) Marketing Effectiveness and Its Relationship to Organizational Culture Characteristics and Output Performance: The South African Experience. Journal of Studies in Economics and Econometrics, 16, 59-78.

[25] Panigyrakis, G. and Chatzipanagiotou, K. (2004) The Relationship between Market Orientation and Marketing Information Systems Effectiveness: An Empirical Investigation. Review of Business Information Systems, 8, 69-82. https://doi.org/10.19030/rbis.v8i4.4478

[26] Kotler, P. (1977) From Sales Obsession to Marketing Effectiveness. Harvard Business Review, 67-75.

[27] Christopher, M., Payne, A.F.T. and Ballantyne, D. (1991) Relationship Marketing: Bringing Quality, Customer Service and Marketing Together. Butterworth Heinemann/CIM, Oxford.

[28] Berry, L. (1981) The Employee as a Customer. Journal of Retail Banking, 3, 33-44. 
[29] Chatzipanagiotou, K., Vassilikopoulou, A. and Siomkos, G. (2008) An Empirical Investigation of the Relationship between Market Orientation and Marketing Effectiveness in Upscale Hotels in Greece. Journal of Targeting, Measurement and Analysis for Marketing, 16, 285-297. https://doi.org/10.1057/jt.2008.20

[30] Berry, L.L. and Parasuraman, A. (1991) Marketing Services: Competing through Quality. The Free Press, New York.

[31] Benjamin, S., Hanges, P.J., Smith, D.B. and Salvaggio, A.N. (2003) Which Comes First: Employee Attitudes or Organizational Financial and Market Performance? Journal of Applied Psychology, 88, 836-851. https://doi.org/10.1037/0021-9010.88.5.836

[32] Avwokemi, A.J. (2005) Practical Project Writing and Oral Presentation. Unicampus Pub., Port Harcourt, 101-192.

[33] Armstrong, M. (2006) A Handbook of Human Resource Management Practice. Kogan Page Publishing, London.

[34] Appiah-Adu, K., Fyall, A. and Singh, S. (2001) Marketing Effectiveness and Business Performance in the Financial Services Industry. Journal of Services Marketing, 15, 18-32. https://doi.org/10.1108/08876040110381346

[35] Ahmed, P.K. and Rafiq, M. (2003) Internal Marketing Issues and Challenges. European Journal of Marketing, 37, 1177-1186. https://doi.org/10.1108/03090560310498813

[36] Ahiauzu, A. (2006) Advance Research Methods in the Management Sciences Port Harcourt. Lecture Notes PhD Class Rivers State University of Science and Technology. 